\title{
Enhanced pore-water nutrient fluxes by the upside-down jellyfish Cassiopea sp. in a Red Sea coral reef
}

\author{
Carin Jantzen ${ }^{1,2,5, *}$, Christian Wild ${ }^{2}$, Mohammed Rasheed ${ }^{3}$, Mohammed El-Zibdah $^{3}$, \\ Claudio Richter ${ }^{4}$ \\ ${ }^{1}$ Leibniz Center for Tropical Marine Ecology (ZMT), Fahrenheitstr. 6, 28359 Bremen, Germany \\ ${ }^{2}$ Coral Reef Ecology (CORE) Work Group, GeoBio-Center, Ludwig-Maximilians Universität, Richard Wagnerstr. 10, \\ 80333 München, Germany \\ ${ }^{3}$ Marine Science Station Aqaba, The University of Jordan and Yarmouk University, PO Box 195, Aqaba, Jordan \\ ${ }^{4}$ Alfred Wegener Institute for Polar and Marine Research, Am Alten Hafen 26, 27568 Bremerhaven, Germany \\ ${ }^{5}$ Present address: Alfred Wegener Institute for Polar and Marine Research, Am Alten Hafen 26, 27568 Bremerhaven, \\ Germany
}

\begin{abstract}
The common circum-tropical jellyfish Cassiopea sp., unlike other members of the Rhizostomidae (Scyphozoa), exhibits a primarily benthic life. The peculiar orientation of its exumbrella against the sediment is believed to be associated with its mainly autotrophic nutrition, i.e. exposing its zooxanthellae-bearing photosynthetic oral appendages to the sunlight. Here we show that the jellyfish also acts as a nutrient pump, drawing nutrient-rich pore waters from the permeable sediments. Depletion of pore-water ammonium in situ, light-enhanced ammonium uptake, and high rates of photosynthesis determined via oxygen flux measurements and underwater fluorometer analysis (rapid light curves) show that Cassiopea sp. effectively harnesses pore-water nutrients. At high densities Cassiopea sp. may facilitate benthic-pelagic coupling and primary production in oligotrophic coral reefs.
\end{abstract}

KEY WORDS: Cassiopea sp. · Upside-down jellyfish · Advective pore-water transport · Nutrient uptake $\cdot$ Nutrient regeneration $\cdot$ Sediment $\cdot$ Photosynthesis $\cdot$ Zooxanthellae

\section{INTRODUCTION}

The upside-down jellyfish Cassiopea sp. (Cnidaria, Scyphozoa, Rhizostomidae) leads a benthic life. It is common in coral reefs, lagoons, seagrass beds and mangroves (Fleck \& Fitt 1999, Arai 2001, Todd et al. 2006), often attaining high densities of up to 30 ind. $\mathrm{m}^{-2}$ (Niggl \& Wild 2009) and higher (e.g. 'countless numbers'; Bigelow 1900, p. 190). Another peculiarity of Cassiopea sp., shared with few other jellyfish (e.g. Linuche unguiculata and Mastigias sp.; Kremer et al. 1990, McCloskey et al. 1994), is its association with photosynthetic dinoflagellates (zooxanthellae). These microalgae live as symbionts in the oral appendages and the bell of Cassiopea sp. Within the bell they are mainly located beneath the exumbrella and particularly beneath the subumbrellar endodermal epithelia (Bigelow 1900, Blanquet \& Riordan 1981), and can reach relatively high densities $\left(1.52 \times 10^{6}\right.$ to $2.68 \times 10^{6}$ cells $\mathrm{mg}^{-1}$ protein; Verde \& McCloskey 1998).

The zooxanthellae provide a major source of energy to the holobiont, so that Cassiopea sp. may act as a functional photoautotroph, depending on light availability (Cates 1975, Verde \& McCloskey 1998). Cassiopea sp. is able to adapt to high light conditions (e.g. in shallow water) and maintains an effective photosynthetic productivity by protecting itself from an excess of harmful UV radiation via the synthesis of myco- 
sporine acids (Banaszak \& Trench 1995), as demonstrated for corals and giant clams (Shick et al. 1995, 1999, Ishikura et al. 1997). Furthermore, Cassiopea sp. has a special blue mesogloeal protein that serves as a shield against damaging solar radiation, while simultaneously allowing photosynthetically active wavelengths to reach the zooxanthellae (Blanquet \& Phelan 1987).

Cassiopea sp. has an upside-down orientation, with the exumbrella facing the substrate, its beating motion and mucus (Gohar \& Eisawy 1960) fixing the animal in place so that 'especially the larger ones would not ordinarily leave the bottom' (Bigelow 1900, p. 191). This unusual modus vivendi of Cassiopea sp. has prompted speculations that the jellyfish's activity may represent a mechanism to maintain its position with respect to sunlight, thus enabling prolonged exposure of the zooxanthellae-laden oral appendages and the subumbrella (Gohar \& Eisawy 1960). It has also been considered a feeding strategy, whereby autotrophic nutrition is accomplished via the capture of interstitial microorganisms flushed across its oral appendages (Larson 1997), entangled in mucus, and subsequently consumed by the many secondary mouths (Bigelow 1900). Nutrient requirements for photosynthesis may partly be met by this digestion of plankton or suspended organic matter.

Cassiopea sp. usually occurs on sandy patches in coral reefs, seagrass beds or mangroves characterised by calm waters. These permeable sandy sediments function as large-scale filter systems (e.g. Hansen et al. 1992, Holguin et al. 2001), where accumulated organic material is effectively decomposed by high abundances of heterotrophic microbes (Wild et al. 2006) and regenerated nutrients are stored interstitially (Rasheed et al. 2002, Wild et al. 2005). Sedimentary nutrient recycling is mainly achieved by anaerobic microbes below a rather thin aerobic layer (Holguin et al. 2001). Under undisturbed conditions few nutrients are released from the sandy sediment to the overlying water column, while the pore water beneath the aerobic layer contains high concentrations of inorganic nutrients. Nutrients are slowly distributed through diffusion and are primarily consumed by microbes within the thin aerobic layer typical for coral reef sands (Wild et al. 2004, Werner et al. 2006), thereby preventing nutrient release in the overlying water column. However, advective transport, e.g. caused by animal activities (Huettel et al. 2003) or bottom water currents, may cause intense release of water with high concentrations of inorganic nutrients from the permeable sediments (Huettel et al. 1998). Nutrients released from coral reef regenerative spaces (crevices and sediments) may play an important role in sustaining primary production in coral reefs (Richter et al. 2001,
Rasheed et al. 2002). It is likely that also Cassiopea sp. may utilise regenerated nutrients for the photosynthesis of its zooxanthellae (Hoegh-Guldberg \& Smith 1989, Rahav et al. 1989, Dubinsky et al. 1990).

The present study explored the so-far untested hypothesis that the jellyfish acts as a nutrient pump releasing sediment-locked nutrients into the overlying water, and then perhaps assimilating them, thus supporting the holobiont's photosynthesis in oligotrophic waters. We studied the jellyfish's pumping performance, nutrient uptake and metabolism (photosynthesis and respiration), as well as the impact of Cassiopea sp. on pore-water nutrient content and its mobility behaviour in situ.

\section{MATERIALS AND METHODS}

Study site. The present study was carried out in the Marine Reserve of the Marine Science Station (MSS), Aqaba, Jordan. Although the Cassiopea species investigated resembles C. andromeda, Holland et al. (2004) point out the difficulty of identifying the species in this genus in the absence of molecular data. Therefore, the generic notation Cassiopea sp. will be used. All investigated specimens revealed similar morphological characteristics and were collected within the same area $\left(100 \mathrm{~m}^{2}\right)$. Similarly sized specimens of Cassiopea sp. were sampled by SCUBA divers, whereby plastic bags rather than nets were used for transportation in order to prevent any harm to the fragile oral appendages. All subsequent experiments were conducted with freshly collected individuals in the outdoor flow-through system at the MSS using small glass or plastic tanks (8 to 10 l). The average diameter of Cassiopea sp. in the experiments was $7.8 \pm 2.7 \mathrm{~cm}$ (mean $\pm \mathrm{SE}_{;} \mathrm{n}=57$ ). All investigations were conducted from November 2007 until April 2008.

Pumping and vertical pore-water flows. Pumping activity of Cassiopea sp. was explored in a series of experiments. The catchment area of pore waters below actively pumping Cassiopea sp. was observed in open tanks $(8 \mathrm{l}, \mathrm{n}=3)$ lined with three, $2 \mathrm{~cm}$ thick, differentcoloured layers of natural, washed sediment: the top layer was un-coloured sediment, the middle layer was dyed with fluorescein (yellow-green) and the bottom layer was dyed with food colour (red). It should be noted that washing and mixing of sediment altered its characteristics in comparison to naturally occurring sediments (e.g. regarding microbial and oxygen vertical distribution). Careful filling of the experimental tanks with natural seawater kept the sediment layers intact. For incubations with fluorescein-dyed sediment, no photosynthetically active radiation (PAR) was measured, as the beat frequency of the bells was inde- 
pendent of the light intensity (unpubl. data). Incubations were performed under a roof without direct sunlight, as fluorescein is degraded by UV (M. Huettel pers. comm.). The movement of the pore waters was monitored photographically in the course of the $14 \mathrm{~h}$ observation period.

Vertical fluxes of pore waters across the sedimentwater interface were quantified by short-term incubations in open tanks (10 l). Again, natural, washed sediment was used, whereby a layer of dyed sediment (fluorescein) was covered with an un-coloured layer. During short-term incubations, water motion was only provided by the jellyfishes' body movement (not by stirring) to prevent distortion of pore-water release. In one set of incubations, the un-dyed top layer had a constant $1 \mathrm{~cm}$ thickness ( $\mathrm{n}=13$, control: $\mathrm{n}=2$ ). In a second set of incubations, the thickness of the top layer varied: $0.5,1,1.5$ or $2 \mathrm{~cm}$ (each $\mathrm{n}=6$ ). For all incubations, water samples were taken in time series after introducing 1 specimen to each tank (first set: at 0, 0.5, 1 and $2 \mathrm{~h}$; second set: at 0.5, 1, 2, 3 and $4 \mathrm{~h}$ ). Fluorescein concentrations of water samples were analysed with a spectral fluorometer (Turner 10-AU-005-CE, excitation $470 \mathrm{~nm}$, emission $514 \mathrm{~nm}$ ). Accumulating fluorescein concentrations in the tank waters over time were used to calculate pore-water release rates, as fluorescein release across the sediment-water interface (nmol $\mathrm{min}^{-1}$ ). For each Cassiopea sp. specimen the bell beat rate $\left(\mathrm{min}^{-1}\right)$ was determined 4 times during each incubation. Area pulse rate was calculated by bell beat rate $\times$ bell area of each specimen $\left(\mathrm{cm}^{-2} \mathrm{~min}^{-1}\right)$. After completing the experiments, the bell diameter (central exumbrellar area including bell margins) of each specimen was measured by placing the live specimen on a measuring tape fixed to the bottom of the holding tank. Bell diameter (D) was recorded between beats, with the relaxed bell lining the bottom. Bell area (A) was calculated according to: $\mathrm{A}=\pi \times(0.5 \times \mathrm{D})^{2}$.

Pore water was collected in situ by taking 'minicores', using truncated $100 \mathrm{ml}$ syringes. Minicores ( $\mathrm{n}=10$ ) were sampled in close vicinity $(<2 \mathrm{~cm})$ of pumping Cassiopea sp. specimens. Control minicores $(n=10)$ were taken in reference areas unaffected by the jellyfishes (>1 m away from Cassiopea sp.). Pore water was extracted after the methods of Rasheed et al. (2002) and pore-water ammonium and phosphate concentrations were analysed according to Grasshoff et al. (1999).

Nutrient uptake. The jellyfishes were incubated in open tanks (as above, 10 l), with $(\mathrm{n}=16)$ and without (control, $\mathrm{n}=8$ ) nutrient solution (ammonium and phosphate). Initial concentrations were $15 \mu \mathrm{M}$ ammonium and $6 \mu \mathrm{M}$ phosphate. Controls showed no detectable nutrient uptake (data not shown). PAR ( $\mu$ mol quanta $\mathrm{m}^{-2}$ $\mathrm{s}^{-1}$ ) was measured with the PAR sensor of a Diving-PAM (see below). Half of the incubations were performed un- der sunlight $\left(856 \pm 129\right.$ PAR $\left[\mu \mathrm{mol}\right.$ quanta $\left.\left.\mathrm{m}^{-2} \mathrm{~s}^{-1}\right]\right)$, the other half under dark conditions (0 PAR [ $\mu$ mol quanta $\left.\left.\mathrm{m}^{-2} \mathrm{~s}^{-1}\right]\right)$, respectively. Water samples were taken in time series after $0,1,2,3$ and $5 \mathrm{~h}$ and filtered through precombusted $\left(450^{\circ} \mathrm{C}\right.$ for $6 \mathrm{~h}$ ) GF/F filters (Whatman, $25 \mathrm{~mm}$ in diameter). Ammonium and phosphate concentrations were analysed according to Grasshoff et al. (1999). Uptake rates ( $\mathrm{nmol} \mathrm{cm} \mathrm{cm}^{-2} \mathrm{~h}^{-1}$ ) were calculated by dividing the product of the concentration differences $\left(\mathrm{nmol} \mathrm{l}^{-1}\right)$ and chamber volumes (l) with the bell surface area $\left(\mathrm{cm}^{2}\right)$ for the respective specimen.

Photosynthetic performance and respiration. Closed-chamber incubations (3 l) were carried out to quantify photosynthesis and respiration via $\mathrm{O}_{2}$ fluxes (e.g. Schneider \& Erez 2006, Borell et al. 2008). Incubations were conducted in gas-tight acrylic chambers at 2 light intensities (see below) and $0.5 \mathrm{~h}$ after sunset (as the Diving-PAM measurements, see below) in a flowthrough water bath with ambient seawater. The chambers were not stirred, as Cassiopea sp. was assumed to mix the water column enclosed in the chambers by its own body movements (which could be observed throughout the incubations). Oxygen concentrations were determined with an Optode (Q 40, Hach-Lange) at the start and end of each chamber incubation. Oxygen fluxes, i.e. rates of oxygen evolution and consumption (net photosynthesis and respiration rates), were calculated as the difference between start and end amounts of oxygen of each incubation $(n=4)$. Rates were normalised to bell area $\left(\mathrm{cm}^{2}\right)$, to obtain a reference for the size of each specimen, yielding $\mu \mathrm{g} \mathrm{O}_{2} \mathrm{~cm}^{-2}$ $\mathrm{min}^{-1}$. Net photosynthesis was determined via lightchamber incubations carried out under direct sunlight at $12: 19$ to $13: 17 \mathrm{~h}$ and $13: 40$ to $14: 50 \mathrm{~h}$. For light measurements, the PAR sensor was placed next to the specimens, and showed mean PAR intensities of $506 \pm$ 150 and $269 \pm 19 \mu \mathrm{mol}$ quanta $\mathrm{m}^{-2} \mathrm{~s}^{-1}$, equivalent to maximum in situ light intensities at 3 to $5 \mathrm{~m}$ and 8 to $12 \mathrm{~m}$ depth (Jantzen et al. 2008) for each incubation, respectively. Respiration was determined via dark chamber incubations (0 PAR [ $\mu$ mol quanta $\left.\mathrm{m}^{-2} \mathrm{~s}^{-1}\right]$ ).

The photosynthetic performance of Cassiopea sp. was further investigated using a submersible pulse amplitude modulated fluorometer (Diving-PAM, Heinz Walz; for details see Schreiber 1986). Three rapid light curves (RLC) were conducted on each of 6 darkadapted Cassiopea sp. specimens $0.5 \mathrm{~h}$ after sunset, when PAR was no longer detectable and the adaptation of the zooxanthellae to dark conditions was likely completed (Durako et al. 2003, Iglesias-Prieto et al. 2004). Eight increasing PAR intensities up to $~ 3000$ $\mu \mathrm{mol}$ quanta $\mathrm{m}^{-2} \mathrm{~s}^{-1}$ were applied for each RLC using the internal settings of the Diving PAM; the electron transport rate (ETR [ $\mu \mathrm{mol} \mathrm{e}^{-} \mathrm{m}^{-2} \mathrm{~s}^{-1}$ ]) was recorded. The ETR is defined as: $\mathrm{PAR} \times\left(\left[\mathrm{Fm}-\mathrm{F}^{\circ}\right] / \mathrm{Fm}\right) \times 0.5$, 


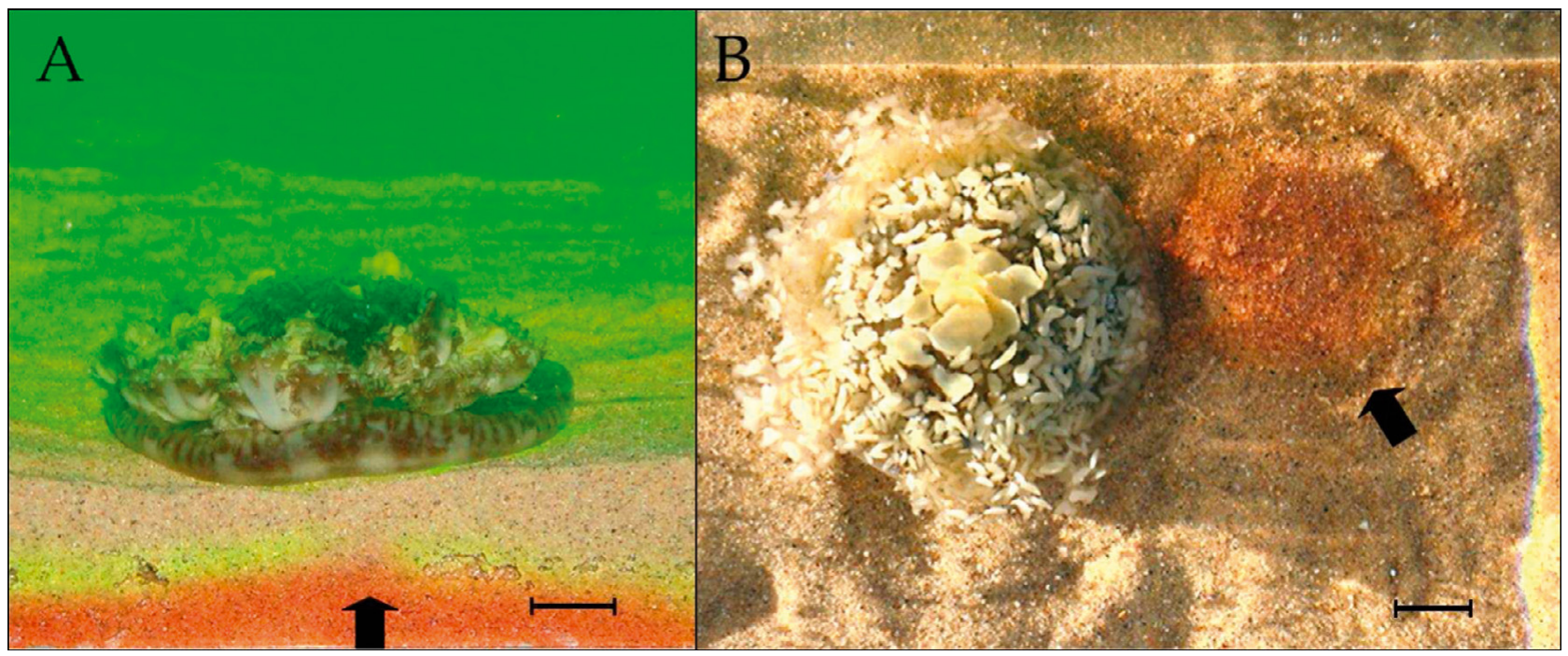

Fig. 1. Cassiopea sp. Pumping activity on coloured sediment. (A) Lateral view of an individual entraining pore water (black arrow) from deeper sediment layers into the water column (greenish hue), as indicated by the doming of yellow and red bands. (B) Red-coloured mould of the concave bell in the sediment (arrow) shows that pore waters from the bottom layer have reached the surface (removed Cassiopea sp. on the left). Red: food colour; yellow: fluorescein, covered by an un-dyed sediment layer. Scale bars $\approx 1 \mathrm{~cm}$

where PAR is the corresponding PAR intensity, ([Fm $\mathrm{F}^{\circ} \mathrm{j} / \mathrm{Fm}$ ) is the potential photosystem II quantum yield and 0.5 represents the assumed uniform distribution of electrons between the 2 photosystems. As no absorption coefficient was defined, this rate is a widely accepted 'relative ETR' (e.g. Glud et al. 2002, Ralph et al. 2002).

Mobility. The mobility of Cassiopea sp. was monitored in situ in an area with high Cassiopea sp. abundance $\left(\mathrm{n}_{\text {total }}=22 ; 9 \mathrm{~m}\right.$ water depth $)$ using a $3 \times 3 \mathrm{~m}$ square subdivided into smaller squares $\left(1 \mathrm{~m}^{2}\right)$. Photographs were taken daily over a $6 \mathrm{~d}$ period (17 to 22 May 2008) and the positions of each individual (identified on the basis of colouring and size) determined. Trajectories of individuals were plotted as progressive vector diagrams and average occupation time $\left(\mathrm{d}^{-1} \mathrm{~m}^{-2}\right)$ was determined.

\section{RESULTS}

\section{Pumping and vertical pore-water flows}

Tank experiments with fluorescein-dyed sediment showed an increase in fluorescein visible as a greenish hue in the tank water (Fig. 1A). The release of fluorescein into the water was accompanied by a doming of the coloured bands in the sediment below the jellyfish (Fig. 1A, black arrow). After $\sim 6 \mathrm{~h}$, pore water from deeper sediment layers reached the surface, as evidenced by the red dye emerging from the circular imprint of the bell on the sediment (Fig. 1B, black arrow shows imprint of bell).

Short-term incubations with Cassiopea sp. revealed linearly increasing fluorescein concentrations with time $\left(2.7 \pm 1.7 \mathrm{nM} \mathrm{min}^{-1}, \mathrm{R}^{2}=0.4\right)$, in contrast to undetectable levels of fluorescein increase in the controls (Fig. 2). The jellyfishes pumped at a rate of $31 \pm 7$ beats $\mathrm{min}^{-1}$, but no correlation between calculated release rates (nmol $\left.\min ^{-1}\right)$ and area pulse rate $\left(\mathrm{cm}^{2} \mathrm{~min}^{-1}\right)$ was found $\left(\mathrm{R}^{2}=\right.$ $0.0007)$. A $2 \mathrm{~cm}$ thick layer of un-coloured sediment delayed dye release by almost $1 \mathrm{~h}(52 \pm 47 \mathrm{~min}$; Fig. S1A,B

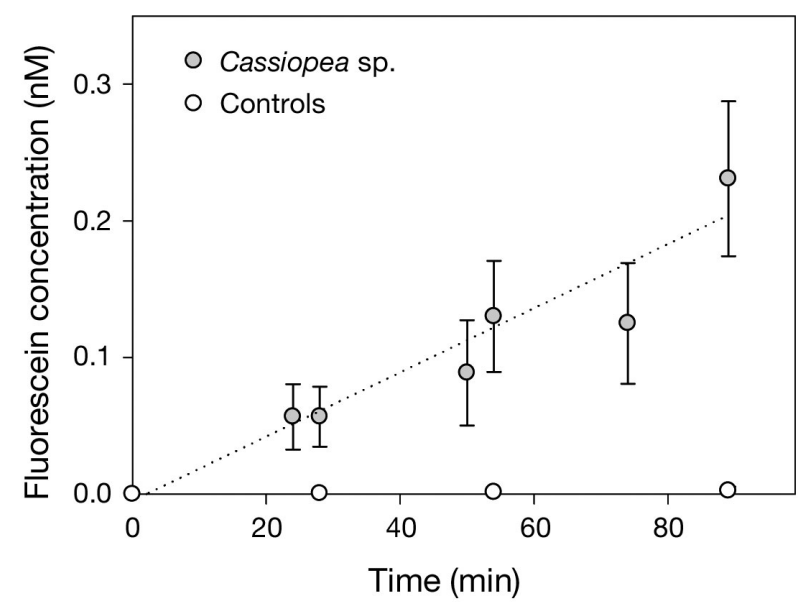

Fig. 2. Cassiopea sp. Pumping activity. Sediment-layer fluorescein accumulates in the water column over time in tanks

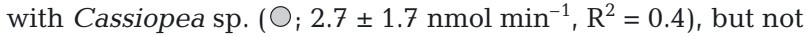
in controls (O). Data are mean $\pm \mathrm{SE}$ 
in Supplement 1, available at www.int-res.com/articles/ suppl/m411p117_supp.pdf). Consequently Cassiopea sp. needed $\sim 1 \mathrm{~h}$ to draw pore water from this depth (Fig. S1B in Supplement 1).

Pore-water sampling in situ revealed significantly lower pore-water ammonium concentrations by $\sim 2 \mu \mathrm{M}$, equal to a reduction of $15 \%$, in the direct vicinity of a pumping jellyfish $(11.99 \pm 1.46 \mu \mathrm{M})$ compared to the adjacent, but undisturbed, sediments (14.07 \pm $1.45 \mu \mathrm{M}_{i}$ Fig. S2 in Supplement $1 ; \mathrm{p}=0.005,2$-sided $t$-test, heterogeneity of variances). However, no corresponding differences in phosphate concentrations were detectable.

\section{Nutrient uptake}

Open-chamber incubations with added nutrient solutions revealed highest uptake rates for ammonium in the light with $5.88 \pm 2.17 \mathrm{nmol} \mathrm{cm}{ }^{-2} \mathrm{~min}^{-1}$ (Fig. S3 in Supplement 1). In contrast, during dark conditions, ammonium uptake was more than 4 times smaller, yielding only $1.29 \pm 0.81 \mathrm{nmol} \mathrm{cm} \mathrm{cm}^{-2} \mathrm{~min}^{-1}$. This difference was highly significant, with $\mathrm{p}<<0.001$ (2-sided $t$ test, heterogeneity of variances).

\section{Photosynthetic performance and respiration}

Closed-chamber incubations with Cassiopea sp. (Fig. 3) revealed maximum net oxygen production rates of $1.66 \pm 0.4 \mu \mathrm{g} \mathrm{O}_{2} \mathrm{~cm}^{-2} \mathrm{~min}^{-1}$ at high PAR intensities $\left(506 \pm 150 \mu \mathrm{mol}\right.$ quanta $\left.\mathrm{m}^{-2} \mathrm{~s}^{-1}\right)$. Corresponding

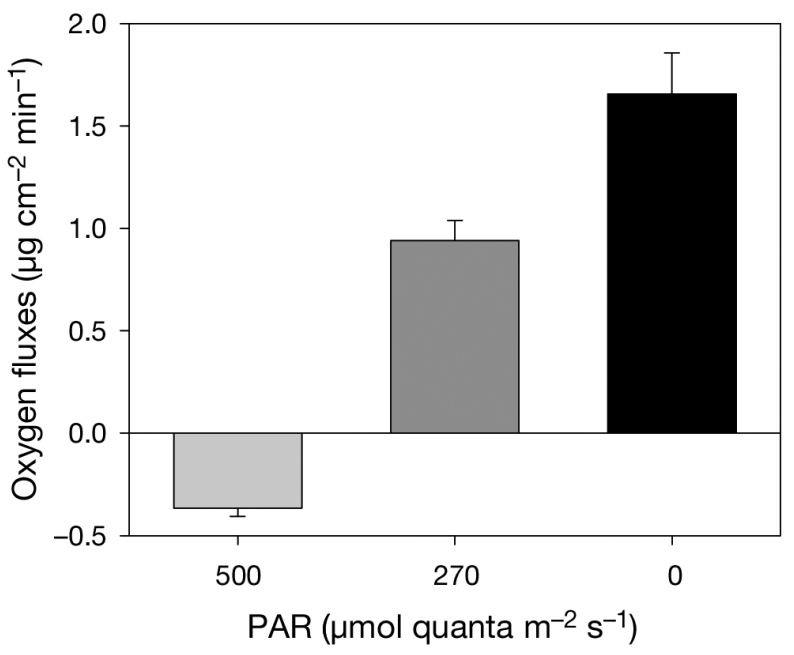

Fig. 3. Cassiopea sp. Net photosynthesis and respiration rates. Oxygen fluxes (normalised per bell area) determined under 2 light intensities (506 \pm 150 and $269 \pm 19 \mu \mathrm{mol}$ quanta $\mathrm{m}^{-2} \mathrm{~s}^{-1}$ ) and in the dark. PAR: photosynthetically active radiation. Data are mean $\pm \mathrm{SE}$

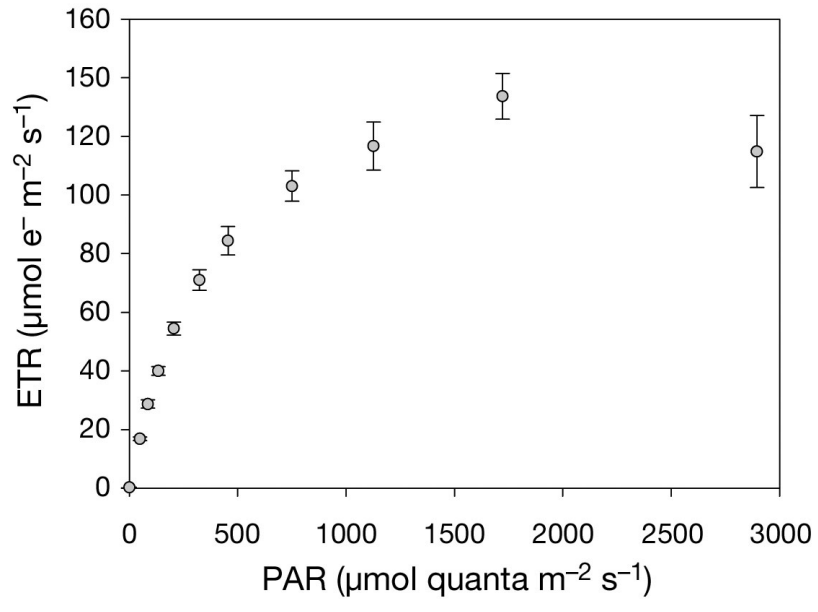

Fig. 4. Cassiopea sp. Dark-adapted rapid light curves (RLC). Electron transport rate (ETR) with increasing light intensities (photosynthetically active radiation [PAR]) shows no saturation up to 2-fold maximum ambient light conditions. Data are mean $\pm \mathrm{SE}$

values at moderate PAR levels $(269 \pm 19$ umol quanta $\mathrm{m}^{-2} \mathrm{~s}^{-1}$ ) were $0.94 \pm 0.2 \mu \mathrm{g} \mathrm{O}_{2} \mathrm{~cm}^{-2}$. Respiration rates were low $\left(0.37 \pm 0.08 \mu \mathrm{g} \mathrm{O}_{2} \mathrm{~cm}^{-2}\right)$, resulting in a high quotient of net photosynthesis to respiration (Q) of 2.6 to 4.5 , depending on light conditions.

RLCs of dark-adapted Cassiopea sp. showed no saturation in ETR at up to 2-fold maximum ambient light intensities, revealing Cassiopea sp. capable of maintaining an efficient photosynthesis even under very high light intensities (Fig. 4). Maximum photosynthesis was on average 130 ETR ( $\mu \mathrm{mol} \mathrm{e}^{-} \mathrm{m}^{-2} \mathrm{~s}^{-1}$ ) and individually up to $178 \mathrm{ETR}\left(\mu \mathrm{mol} \mathrm{e}^{-} \mathrm{m}^{-2} \mathrm{~s}^{-1}\right)$.

\section{Mobility}

Photographic documentation on a scaled area revealed a relatively long residence time of conservatively $2.8 \pm 1.7 \mathrm{~d}$ within $1 \mathrm{~m}^{2}$. Some of the jellyfishes were already present before $(n=15)$, or remained after the end of, the documentation $(n=7)$, or both $(n=2)$. A vector diagram showing Cassiopea sp.'s movements is given in Fig. S4 in Supplement 1.

\section{DISCUSSION}

The present study, along with a recent paper on the related rhizostome Mastigias sp. (Katija \& Dabiri 2009), is the first demonstration so far of jellyfish-mediated active vertical transport of nutrients across the interface separating oligotrophic surface waters from nutrient-replete interstitial and subthermocline deep water, 
respectively. Our behavioural observations and nutrient and fluorescein-tracer measurements clearly show that the jellyfish release sediment-locked nutrient-rich pore waters into the overlying waters and are capable of utilising free ammonium. Ammonium uptake is enhanced by light, suggesting that photosynthesis is involved in the process. But how distinct are these sediment-water fluxes?

\section{Pumping performance and pore-water flows}

Permeable sandy sediments with their associated microbiota act as large-scale filters that trap organic matter and recycle and store this material in inorganic form as interstitial nutrients (Hansen et al. 1992, Holguin et al. 2001, Rasheed et al. 2002, Wild et al. 2006). The diffusive fluxes of these sedimentary nutrients into the overlying reef water are only poor (Al-Rousan et al. 2004). Currents and waves interacting with the sediment topography (i.e. sand ripples) may enhance nutrient fluxes by several orders of magnitude (Huettel \& Rusch 2000, Huettel \& Webster 2001, Rasheed et al. 2003). However, away from the surface, where waves and currents are weak (Precht \& Huettel 2003), particularly in the Gulf of Aqaba where horizontal currents average only a few $\mathrm{cm} \mathrm{s}^{-1}$ (Genin \& Paldor 1998, Manasrah et al. 2006), bioturbation becomes more important. Goat fish have been shown to plough the upper centimetres of reef sediments in search of invertebrate food (Yahel et al. 2002), and mud shrimp may ventilate the sediments up to $>1 \mathrm{~m}$ (Ziebis et al. 1996). Small disturbances as they commonly occur in the present study area, such as interactions between bottom water currents and sediment topography (Ziebis et al. 1996), wave influence (Precht \& Huettel 2003) or bioturbation (Huettel et al. 2003), can cause considerable advective pore-water exchange and subsequent release of nutri- ents from the permeable sediments into the water column. The present study revealed that advective transport of pore-water nutrients may also be induced by the pumping movements of Cassiopea sp.

Our report is the first of a gelatinous organism releasing interstitial nutrients in considerable quantities from a depth of $2 \mathrm{~cm}$ within $1 \mathrm{~h}$. While the biomechanical details are beyond the scope of the present paper, it is clear from our preliminary observations that the nutrient release is associated with the motion of the exumbrella against the substrate (Movie 1 in Supplement 2, available at www.int-res.com/articles/suppl/ m411p117_supp/). The muscular contraction of the bell, antagonised by the flat or slightly cup-shaped mesogloea (Gladfelter 1972) sealed off against its margin with mucus (Gohar \& Eisawy 1960; Movie 2 in Supplement 2), creates a pressure gradient drawing nutrient pore water up and into the jet of water forced through the oral appendages (Fig. 5). In contrast to corals and other sessile functional phototrophs, which are entirely at the mercy of the currents supplying essential nutrients to the passive animals, the mobile jellyfish Cassiopea sp. may actively enrich its nutrient environment by pumping nutrients from the sediments.

Small jellyfish (Polyorchis penicillatus, $<3 \mathrm{~cm}$ diameter) expend between $8.9 \times 10^{-5}$ and $14.0 \times 10^{-5} \mathrm{~J}$ in the contraction phase, and between $1.7 \times 10^{-5}$ and 2.1 $\times 10^{-5} \mathrm{~J}$ in the refilling phase of their swimming bells (DeMont \& Gosline 1988a,b). For the $\sim 1$ order of magnitude larger Cassiopea sp. in the present study $(\times 3$ by bell diameter, equivalent to a conservative $\times 10$ by bell volume and mass, considering the flat shape of the bell), we may conservatively assume an order of magnitude higher force (mass $\times$ acceleration) and energy (force $\times$ displacement), i.e. $\sim 2 \times 10^{-4} \mathrm{~J}$ in the refilling phase of their beat cycle. If we assume that this energy is used to refill both exumbrellar and subumbrellar

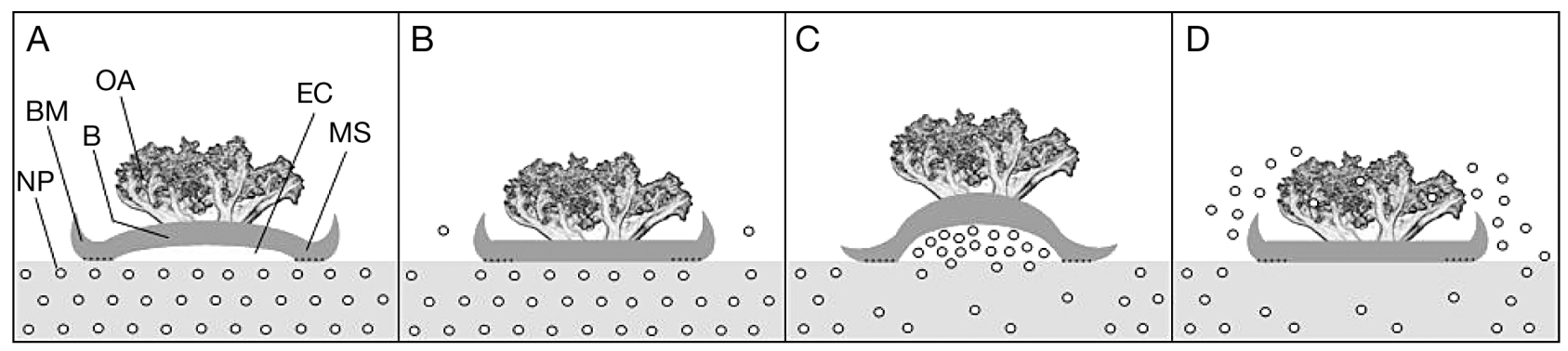

Fig. 5. Cassiopea sp. Scheme of pumping activity on sediment. (A) Freshly settled specimen on the sediment, revealing the concave exumbrella. (B) Contraction of the muscles causes the bell to flatten, forcing the enclosed water sideways into the overlying water. (C) The subsequent relaxation of the muscles allows the flexed bell to re-gain its former cup-like shape; the growing exumbrellar cavity sealed off at the bell margins draws pore waters into the exumbrellar space. (D) Contraction of the bell (beat) flushes nutrient-rich water out sideward, enriching the zooxanthellae-bearing oral appendages with nutrients. B: bell; BM: bell margins; EC: exumbrellar cavity; MS: mucus sealed bell seating; NP: nutrient-rich pore water; OA: oral appendages. Note that the vertical-scale exumbrellar cavity is exaggerated 
spaces in the concave-shaped exumbrella of Cassiopea sp. (as opposed to Polyorchis spp. and other free-swimming medusae with convex exumbrellae, where only the subumbrella can be filled), this leaves us with an energy $\mathrm{E}$ of $\sim 1 \times 10^{-4} \mathrm{~J}$ to refill the exumbrellar space (assuming that the energy is partitioned to both sides of the bell in equal proportions). If we now consider Cassiopea sp.'s exumbrella to function as a d $=10 \mathrm{~cm}$ diameter suction piston with $\mathrm{h}=5 \mathrm{~mm}$ vertical displacement, this energy may be used to draw porewater flows upwards, as long as the mucus-lined bell margin acts as a seal isolating the exumbrellar space from the boundary layer waters. The corresponding upward force can be calculated as $\mathrm{F}=\mathrm{E} / \mathrm{h}=0.0001 \mathrm{~J} /$ $0.005 \mathrm{~m}=0.02 \mathrm{~N}$. This force $\mathrm{F}$ exerted on a $\mathrm{d}=0.1 \mathrm{~m}$ diameter circular area $\left(\mathrm{A}=\pi \times(\mathrm{d} / 2)^{2}\right)$ may thus generate a horizontal pressure gradient of $\mathrm{p}=\mathrm{F} / \mathrm{A}=2.5 \mathrm{~Pa}$ between the exumbrella-covered and adjacent sediment areas. Such a pressure gradient may potentially drive pore-water flows between 0.4 and $>3.7 \mathrm{l} \mathrm{m}^{-2} \mathrm{~h}^{-1}$ with washout depths between 2.5 and $>10 \mathrm{~cm}$, depending on the permeability of the sediment (Huettel \& Gust 1992). However, no hydro-dynamical investigations were conducted, as they were beyond the scope of the present study, and therefore no concrete conclusions could be drawn.

Precht \& Huettel (2003) investigated wave-induced pressure gradients around $1.1 \mathrm{~Pa}$ across the sedimentwater interface driving flows of $116 \mathrm{l} \mathrm{m}^{-2} \mathrm{~d}^{-1}$. Rasheed et al. (2004) found that a similar pressure gradient (1.2 Pa between the centre and rim of a stirred chamber) induced flow velocities around $0.6 \mathrm{~cm} \mathrm{~s}^{-1}$, equivalent to a 4 -fold pore-water release compared to diffusive fluxes.

The overall amount of released nutrients depends on the jellyfishes' densities. Cassiopea sp. covers an average of $3 \%$ of the sediment areas at the Marine Reserve of the MSS and may attain abundances of up to 30 ind. $\mathrm{m}^{-2}$ (Niggl \& Wild 2009); they are also common in Caribbean lagoons (Arai 2001) and mangrove ecosystems along Florida (Fleck \& Fitt 1999). Where they occur in high densities or 'countless numbers' (e.g. in Jamaica; Bigelow 1900), this jellyfish may furnish a substantial supply of otherwise unavailable sedimentlocked nutrients in oligotrophic coral-reef waters.

The lack of correlation between fluorescence tracer release and Cassiopea sp. area pulse rate suggests that other factors unaccounted for in our experiments play a role in generating the pressure gradient driving the vertical flux of pore waters, such as the tightness of the mucus seal around the bell margin or varying pumping forces of the individual jellyfish. Data on the biomechanics of Cassiopea sp. pumping and induced porewater flows are lacking and need to be characterised in future studies.
Although jellyfish have only recently been shown to enhance the vertical flux of nutrients in the pelagic realm (Katija \& Dabiri 2009), Cassiopea sp. is the only example to the best of our knowledge of a gelatinous ecosystem engineer enhancing the supply of nutrients in coral reefs.

\section{Nutrient uptake}

Cassiopea sp. assimilated ammonium, known to be the preferred nitrogen source for symbiont-bearing cnidarians (Muscatine 1978, Burris 1983, Wilkerson \& Trench 1986). Ammonium absorption by Cassiopea sp. was considerably enhanced under sunlight, indicating a stimulation of ammonium uptake by photosynthesis. This effect has also been found for other zooxanthellae-bearing organisms, such as the coral Stylophora pistillata (Grover et al. 2002) and other hosts (Summons et al. 1986). The jellyfish revealed a high photosynthetic efficiency under high light levels (as demonstrated by the RLCs), comparable to corals under similar light intensities (Ralph et al. 1999, 2002). Furthermore, Cassiopea sp. exhibited a high net photosynthesis to respiration quotient $(\mathrm{Q})$, hinting towards functional autotrophy, as supported by the studies of Cates (1975) and Verde \& McCloskey (1998). Therefore Cassiopea sp. is in need of organic nutrients to support the production of photosynthates by its symbionts. Despite intensive recycling of nutrients within the cnidarian-zooxanthellae symbiosis that retains essential nutrients inside the holobiont (Muscatine \& Porter 1977, Falkowski et al. 1984, Rees 1986), and evidence indicating an uptake of host-derived ammonium by the zooxanthellae (Cates \& McLaughlin 1976), Cassiopea sp. can profit from the release of fresh porewater nutrients induced by its own body movement.

Acknowledgements. We are indebted to L. Colgan and L. Kamphausen for their great dedication and help during the short-term incubations and the mobility study. C. Wabnitz assisted with the in situ video work. We thank A. Khalili, M. R. Morad and M. Huettel for their valuable advice on this study. Thanks are due to ZMT for funding and to the directors and staff of the MSS and the ZMT for logistic support. Thanks to W. Niggl for fruitful discussions on the manuscript. Special thanks are due to the anonymous reviewers who assisted in improving the manuscript.

\section{LITERATURE CITED}

Al-Rousan S, Rasheed M, Badran M (2004) Nutrient diffusive fluxes from sediments in the northern Gulf of Aqaba, Red Sea. Sci Mar 68:483-490

> Arai MN (2001) Pelagic coelenterates and eutrophication: a review. Hydrobiologia 451:69-87

> Banaszak AT, Trench RK (1995) Effects of ultraviolet (UV) radiation on marine microalgal-invertebrate symbioses. II. 
The synthesis of mycosporine-like amino acids in response to exposure to UV in Anthopleura elegantissima and Cassiopea xamachana. J Exp Mar Biol Ecol 194:233-250

Bigelow RP (1900) The anatomy and development of Cassiopea xamachana. Boston Soc Nat Hist Mem 5:191-236

Blanquet RS, Phelan MA (1987) An unusual blue mesogleal protein from the mangrove jellyfish Cassiopea xamachana. Mar Biol 94:423-430

Blanquet RS, Riordan GP (1981) An ultrastructural study of the subumbrellar musculature and desmosomal complexes of Cassiopea xamachana (Cnidaria: Scyphozoa). Trans Am Microsc Soc 100:109-119

Borell EM, Yuliantri AR, Bischof K, Richter C (2008) The effect of heterotrophy on photosynthesis and tissue composition of two scleractinian corals under elevated temperature. J Exp Mar Biol Ecol 364:116-123

Burris RH (1983) Uptake and assimilation of ${ }^{15} \mathrm{NH}_{4}{ }^{+}$by a variety of corals. Mar Biol 75:151-155

Cates N (1975) Productivity and organic consumption in Cassiopea and Conductylus. J Exp Mar Biol Ecol 18:55-59

> Cates N, McLaughlin JA (1976) Differences of ammonium metabolism in symbiotic and aposymbiotic Condylactus and Cassiopea spp. J Exp Mar Biol Ecol 21:1-5

DeMont ME, Gosline JM (1988a) Mechanics of the jet propulsion in the hydromedusan jellyfish Polyorchis penicillatus I. Mechanical properties of the locomotor structure. J Exp Biol 134:313-332

DeMont ME, Gosline JM (1988b) Mechanics of the jet propulsion in the hydromedusan jellyfish Polyorchis penicillatus II. Energetics of the jet cycle. J Exp Biol 134:333-345

Dubinsky Z, Stambler N, Ben-Zion M, McCloskey LR, Muscatine L, Falkowski PG (1990) The effect of external nutrient resources on the optical properties and the photosynthetic efficiency of Stylophora pistillata. Proc R Soc Lond B 239: 231-246

Durako MJ, Kunzelman JI, Kenworthy WJ, Hammerstrom KK (2003) Depth-related variability in the photobiology of two populations of Halophila johnsonii and Halophila decipiens. Mar Biol 142:1219-1228

Falkowski PG, Dubinsky Z, Muscatine L, Porter JW (1984) Light and bioenergetics of a symbiotic coral. Bioscience 34:705-709

> Fleck J, Fitt WK (1999) Degrading mangrove leaves of Rhizophora mangle Linne provide a natural cue for settlement and metamorphosis of the upside-down jellyfish Cassiopea xamachana Bigelow. J Exp Mar Biol Ecol 234:83-94

Genin A, Paldor N (1998) Changes in the circulation and current spectrum near the tip of the narrow seasonally mixed Gulf of Eilat. Isr J Earth Sci 47:87-92

Gladfelter WB (1972) Structure and function of the locomotory system of the Seyphomedusa Cyanea capillata. Mar Biol 14:150-160

Glud RN, Rysgaard S, Kühl M (2002) A laboratory study on $\mathrm{O}_{2}$ dynamics and photosynthesis in ice algal communities: quantification by microsensors, $\mathrm{O}_{2}$ exchange rates, ${ }^{14} \mathrm{C}$ incubations and a PAM fluorometer. Aquat Microb Ecol 27:301-311

Gohar HAF, Eisawy AM (1960) The biology of the Cassiopea andromeda. Publ Mar Biol Stn Al-Ghardaqa 11:148-190

Grasshoff K, Ehrhardt M, Kremling K (1999) Methods of seawater analysis, 3rd edn. Verlag Chemie, Weinheim

Grover R, Maguer JF, Reynaud-Vaganay S, Ferrier-Pagès C (2002) Uptake of ammonium by scleractinian coral Stylophora pistillata: effect of feeding, light, and ammonium concentration. Limnol Oceanogr 47:782-790

> Hansen JA, Klumpp DW, Alongi DM, Dayton PK, Riddel MJ (1992) Detrital pathways in a coral reef lagoon. II. Detritus deposition, benthic microbial biomass and production. Mar Biol 113:363-372

> Hoegh-Guldberg O, Smith GJ (1989) Influence of the population density of zooxanthellae and supply of ammonium on the biomass and metabolic characteristics of the reef corals Seriatophora hystrix and Stylophora pistillata. Mar Ecol Prog Ser 57:173-186

Holguin G, Vazquez P, Bashan Y (2001) The role of sediment microorganisms in the productivity, conservation, and rehabilitation of mangrove ecosystems: an overview. Biol Fertil Soils 33:265-278

> Holland BS, Dawson MN, Crow GL, Hofmann DK (2004) Global phylogeography of Cassiopea (Scyphozoa: Rhizostomeae): molecular evidence for cryptic species and multiple invasions of the Hawaiian Islands. Mar Biol 145: 1119-1128

Huettel M, Gust G (1992) Solute release mechanisms from confined sediment cores in stirred benthic chambers and flume flows. Mar Ecol Prog Ser 82:187-197

> Huettel M, Rusch A (2000) Transport and degradation of phytoplankton in permeable sediment. Limnol Oceanogr 45:534-549

Huettel M, Webster IT (2001) Porewater flow in permeable sediments. In: Boudreau BP, Jørgensen BB (eds) The benthic boundary layer. Oxford University Press, Oxford, p 144-179

> Huettel M, Ziebis W, Forster S, Luther GW (1998) Advective transport affecting metal and nutrient distributions and interfacial fluxes in permeable sediments. Geochim Cosmochim Acta 62:613-631

> Huettel M, Roy H, Precht E, Ehrenhauss S (2003) Hydrodynamical impact on biogeochemical processes in aquatic sediments. Hydrobiologia 494:231-236

Iglesias-Prieto R, Beltran VH, LaJeunesse TC, Reyes-Bonilla $H$, Thome PE (2004) Different algal symbionts explain the vertical distribution of dominant reef corals in the eastern Pacific. Proc R Soc Lond B 271:1757-1763

Ishikura M, Kato C, Maruyama T (1997) UV-absorbing substances in zooxanthellate and azooxanthellate clams. Mar Biol 128:649-655

> Jantzen C, Wild C, El-Zibdeh M, Roa-Quiaoit HA, Haacke C, Richter C (2008) Photosynthetic performance of giant clams, Tridacna maxima. Mar Biol 155:211-221

Katija K, Dabiri JO (2009) A viscosity-enhanced mechanism for biogenic ocean mixing. Nature 460:624-627

> Kremer P, Costello J, Kremer J, Canino M (1990) Significance of photosynthetic endosymbionts to the carbon budget of the scyphomedus Linuche unguiculata. Limnol Oceanogr 35:609-624

Larson RJ (1997) Feeding behaviour of Caribbean Scyphomedusae: Cassiopea frondosa (Pallas) and Cassiopea xamachana (Bigelow). Publ Found Sci Res Caribb Reg 139: 43-54

> Manasrah RS, Al-Horani FA, Rasheed MY, Al-Rousan SA, Khalaf MA (2006) Patterns of summer vertical and horizontal currents in coastal waters of the northern Gulf of Aqaba, Red Sea. Estuar Coast Shelf Sci 69:567-579

McCloskey LR, Muscatine L, Wilkerson FP (1994) Daily photosynthesis, respiration, and carbon budgets in a tropical marine jellyfish (Mastigias sp.). Mar Biol 119:13-22

> Muscatine L (1978) The uptake, retention, and release of ammonium by reef corals. Limnol Oceanogr 23:725-734

Muscatine L, Porter JW (1977) Reef corals: mutualistic symbiosis adapted to nutrient-poor environments. Biomed Sci 27:454-460

Niggl W, Wild C (2009) Spatial distribution of the upsidedown jellyfish Cassiopea sp. within fringing coral reef 
environments of the Northern Red Sea: implications for its life cycle. Helgol Mar Res doi:10.1007/s10152-009-0181-8

Precht E, Huettel M (2003) Advective pore-water exchange driven by surface gravity waves and its ecological implications. Limnol Oceanogr 48:1674-1684

Rahav O, Dubinsky Z, Achituv Y, Falkowski PG (1989) Ammonium metabolism in the zooxanthellate coral Stylophora pistillata. Proc R Soc Lond B 236:325-337

Ralph PJ, Gademann R, Larkum AWD, Schreiber U (1999) In situ underwater measurements of photosynthetic activity of coral zooxanthellae and other reef-dwelling dinoflagellate endosymbionts. Mar Ecol Prog Ser 180: 139-147

Ralph PJ, Gademann R, Larkum AWD, Kühl M (2002) Spatial heterogeneity in active chlorophyll fluorescence and PSII activity of coral tissues. Mar Biol 141:639-646

Rasheed M, Badran MI, Richter C, Huettel M (2002) Effect of reef framework and bottom sediment on nutrient enrichment in a coral reef of the Gulf of Aqaba, Red Sea. Mar Ecol Prog Ser 239:277-285

Rasheed M, Badran M, Huettel M (2003) Influence of sediment permeability and mineral composition on organic matter degradation in three sediments from the Gulf of Aqaba, Red Sea. Estuar Coast Shelf Sci 57:369-384

Rasheed M, Wild C, Franke U, Huettel M (2004) Benthic photosynthesis and oxygen consumption in permeable carbonate sediments at Heron Island, Great Barrier Reef, Australia. Estuar Coast Shelf Sci 59:139-150

Rees TAV (1986) The green hydra symbiosis and ammonium. I. The role of the host in ammonium assimilation and its possible regulatory significance. Proc R Soc Lond B 229: 299-314

Richter C, Wunsch M, Rasheed M, Kötter I, Badran MI (2001) Endoscopic exploration of Red Sea coral reefs reveals dense populations of cavity-dwelling sponges. Nature 413:726-730

Schneider K, Erez J (2006) The effect of carbonate chemistry on calcification and photosynthesis in the hermatypic coral Acropora eurystoma. Limnol Oceanogr 51: 1284-1293

Schreiber U (1986) Detection of rapid induction kinetics with a new type of high-frequency modulated chlorophyll fluorometer. Photosynth Res 9:261-272

Shick JM, Lesser MR, Dunlap WC, Stochaj WR, Chalker BE, Wu Won J (1995) Depth dependent responses to solar

Editorial responsibility: Matthias Seaman,

Oldendorf/Luhe, Germany ultraviolet radiation and oxidative stress in the zooxanthellate coral Acropora microphthalma. Mar Biol 122:41-51

Shick JM, Romaine-Lioud S, Ferrier-Pages C, Gattuso JP (1999) Ultraviolet-B radiation stimulates shikimate pathwaydependent accumulation of mycosporine-like amino acids in the coral Stylophora pistillata despite decreases in its population of symbiotic dinoflagellates. Limnol Oceanogr 44:1667-1682

Summons RE, Boag TS, Osmond CB (1986) The effect of ammonium on photosynthesis and the pathway of ammonium assimilation in Gymnodinium microadriaticum in vitro and in symbiosis with tridacnid clams and corals. Proc R Soc Lond B 227:147-159

Todd BD, Thornhill DJ, Fitt WK (2006) Patterns of inorganic phosphate uptake in Cassiopea xamachana: a bioindicator species. Mar Pollut Bull 52:515-521

Verde EA, McCloskey LR (1998) Production, respiration and photophysiology of the mangrove jellyfish Cassiopea xamachana symbiotic with zooxanthellae: effect of jellyfish size and season. Mar Ecol Prog Ser 168:147-162

- Werner U, Bird P, Wild C, Ferdelman T, and others (2006) Spatial variability of aerobic and anaerobic mineralization in coral reef sediments (Heron Island, Australia). Mar Ecol Prog Ser 309:93-105

> Wild C, Rasheed M, Werner U, Franke U, Johnstone R, Huettel M (2004) Degradation and mineralization of coral mucus in reef environments. Mar Ecol Prog Ser 267: 159-171

Wild C, Rasheed M, Jantzen C, Cook P, Struck U, Huettel M, Boetius A (2005) Benthic metabolism and degradation of natural particulate organic matter in carbonate and silicate reef sands of the northern Red Sea. Mar Ecol Prog Ser 298:69-78

Wild C, Laforsch C, Huettel M (2006) Detection and enumeration of microbial cells within highly porous calcareous reef sands. Mar Freshw Res 57:415-420

Wilkerson FP, Trench RK (1986) Uptake of dissolved inorganic nitrogen by the symbiotic clam Tridacna gigas and the coral Acropora sp. Mar Biol 93:237-246

Yahel R, Yahel G, Genin A (2002) Daily cycles of suspended sand at coral reefs: a biological control. Limnol Oceanogr 47:1071-1083

> Ziebis W, Forster S, Huettel M, Jorgensen BB (1996) Complex burrows of the mud shrimp Callianassa truncata and their geochemical impact in the sea bed. Nature 382:619-622

Submitted: August 31, 2009; Accepted: April 14, 2010

Proofs received from author(s): July 8, 2010 